\title{
KARAKTERISTIK SPASIAL TEMPORAL KONDISI OSEANOGRAFI LAUT BANDA DAN HUBUNGANNYA DENGAN POTENSI SUMBERDAYA PERIKANAN
}

\author{
Adi Wijaya $^{\mathrm{a}, \mathrm{b},}$ *, Bayu Priyono ${ }^{\mathrm{b}}$, Nadya Christa Mahdalena ${ }^{\mathrm{c}}$ \\ ${ }^{a}$ Mahasiswa Program Doktor Ilmu Perikanan dan Kelautan Universitas Brawijaya Malang, Jalan Veteran \\ No. 1 Malang Jawa Timur \\ ${ }^{\mathrm{b}}$ Peneliti di Balai Riset dan Observasi Laut-KKP, Jalan Baru Perancak Negara Jembrana Bali \\ ${ }^{c}$ Laboran Laboratorium Observasi dan Pemodelan Laut-LRK Balai Riset dan Observasi Laut-KKP, Jalan \\ Baru Perancak Negara Jembrana Bali
}

*Corresponding Author: adi.wijaya@student.ub.ac.id atau adi.wijaya@kkp.go.id

\begin{abstract}
Abstrak
Laut Banda merupakan wilayah perairan dengan potensi yang tinggi dalam bidang perikanan. Kondisi tersebut ditunjukkan dengan musim penangkapan ikan yang tinggi. Makalah ini bertujuan untuk melihat keterkaitan antara kondisi oseanografi fisik dengan hasil penangkapan ikan tuna, tongkol dan cakalang yang didaratkan di Pelabuhan Perikanan Nusantara (PPN) Ambon pada tahun 2015. Data yang digunakan merupakan data perata-rataan bulanan keluran model INDESO secara 3 dimensi yang meliputi suhu, salinitas dan arus dengan resolusi spasial 1/12 derajat. Berdasarkan data ikan tuna tertangkap pada kisaran suhu 16-18 ${ }^{0} \mathrm{C}$, salinitas 34-34,5 PSU, arus 0,1-0,05 m/s pada kedalam > $200 \mathrm{~m}$; ikan tongkol tertangkap pada kisaran suhu 20-22 ${ }^{\circ} \mathrm{C}$, salinitas 34-34,5 PSU, arus 0,1-0,05 m/s pada kedalaman < $100 \mathrm{~m}$; dan ikan cakalang tertangkap pada kisaran suhu $29,5-31{ }^{\circ} \mathrm{C}$, salinitas $31-33 \mathrm{PSU}$, arus $0,15-0,30 \mathrm{~m} / \mathrm{s}$ pada kedalaman $<100 \mathrm{~m}$. Hasil penelitian bahwa kondisi suhu, salinitas dan arus secara vertical di Laut Banda pada kedalaman < 100 dan > $200 \mathrm{~m}$, menunjukkan peningkatan hasil tangkapan pada musim peralihan II (September-November) dan musim barat, sedangkan pada musim peralihan I (Maret-Mei) dan timur mengalami penurunan.
\end{abstract}

Kata Kunci: Arus, Cakalan, Salinitas, Suhu, Tongkol, Tuna

\begin{abstract}
The Banda Sea is an area of water with a high potential in the field of fisheries. The condition is indicated by high fishing season. This paper aims to examine the relationship between physical oceanographic conditions with tuna, tuna and skipjack catch landed at the Ambon Fishing Port (PPN) of Ambon in 2015. The data used are monthly average monthly data of INDESO model of the model which includes temperature, salinity and current with 1/12-degree spatial resolution. Based on data of tuna fish caught at temperature range $16-18{ }^{0} \mathrm{C}$, salinity 34-34,5 PSU, current $0,1-0,05 \mathrm{~m} / \mathrm{s}$ at $>200 \mathrm{~m}$ deep; tuna fish caught at temperature range $20-22{ }^{0} \mathrm{C}$, salinity $34-34,5 \mathrm{PSU}$, current $0,1-0,05 \mathrm{~m} / \mathrm{s}$ at depth $<100 \mathrm{~m}$; and skipjack caught at temperature range $29,5-31{ }^{0} \mathrm{C}$, salinity 31-33 PSU, current $0,15-0,30 \mathrm{~m} / \mathrm{s}$ at depth $<100 \mathrm{~m}$. The results showed that the conditions of temperature, salinity and current vertically in the Banda Sea at depths of $<100$ and $>200 \mathrm{~m}$, showed an increase in a catch during the transition period II (September-November) and the west season, while in the transition season I (March-May) and the east has decreased.
\end{abstract}

Keywords: Current, Mackerel, Salinity, Skipjack, Temperature, Tuna

\section{PENDAHULUAN}

Laut Banda merupakan perairan yang berbentuk cekungan (basin) memisahkan paparan sunda di bagian barat dan paparan sahul di bagian timur. Topografi dasar laut yang sangat kompleks dengan bentuk cekungan di bagian barat dan bentuk palung di bagian timur.

Topografi dasar laut tersebut turut menentukan dalam mengendalikan pertukaran massa air laut. Menurut [1], bahwa perairan ini berfungsi sebagai jantung perairan Indonesia. Pada periode monsun barat (DJF) akan terjadi penurunan massa air yang 
berlebih (Downwelling) akibat masuknya air laut dari Laut Jawa dan Flores, serta massa air yang mengalir ke Samudera Pasifik.

Kondisi ini mengakibatkan naiknya suhu permukaan laut dan menurunnya salinitas serta unsusr hara. Sebaliknya jika pada monsun timur (JJA) terjadi pergerakan massa air yang dominan ke arah Laut Flores dan Jawa, sementara massa air laut yang masuk dari Samudera Pasifik kecil maka akan terjadi pengangkatan massa air (upwelling).

Proses penangkatan masaa air di Laut Banda pada musim timur akibat kekosongan massa air pada lapisan paras mengakibatkan penurunan suhu, naiya salinitas dan pengangkatan unsur hara. Ketersediaan unsur hara diperairan akan berpengaruh pada kelimpahan plankton sebagi sumber utama ikan ekonomis penting seperti tuna, tongkol dan cakalang.

Tujuan penulisan makalah ini adalah untuk melihat keterkaitan antara kondisi oseanografi fisik dengan hasil produksi perikanan khususnya ikan Tuna, Tongkol dan Cakalang. Hal ini sangat penting untuk memberikan informasi yang akurat dan actual dalam rangka pembangunan perikanan dan kelautan berbasis perairan tersebut secara berkelanjutan dan bertanggungjawab.

\section{BAHAN DAN METODE}

Daerah penelitian merupakan Laut Banda dengan koordinat $2,5^{0}-9^{0} \mathrm{LS} ; 126^{0}-131,5^{0}$ BT. Data yang digunakan dalam penelitian ini adalah parameter oseanografi fisik dengan parameter suhu, salinitas dan arus. Parameter fisik oseanografi di peroleh dari data peratarataan bulanan keluaran model INDESO secara 3 dimensi dengan resolusi spasial 1/12 derajat yang diunduh dari laman www.indeso.web.id. Data produksi perikanan di peroleh dari Pelabuhan Perikanan Nasional (PPN) Ambon. Periode data parameter oseanografi fisik dan perikanan yang digunakan dalam penelitian ini adalah data bulanan selama tahun 2015. Semua data spasial dan temporal parameter oseanografi fisik diplotkan menggunakan program Matlab. Hubungan antara parameter oseanografi dan perikanan dengan analisis disktiptif dengan melihat pola secara ruang dan waktu terhadap parameter oseanografi fisik dan perikanan khususnya Tuna, tongkol dan cakalang.

\section{HASIL DAN PEMBAHASAN}

\section{Distribusi Suhu dan Permukaan Laut}

Rata-rata suhu permukaan laut bulanan selama tahun 2015 di Laut Banda yang ditunjukkan pada (Gambar 1, pada umumnya berkisar antara 23 sampai dengan $33^{\circ} \mathrm{C}$, sesuai dengan hasil beberapa penelitian sebelumnya [2]-[5]. Hasil analisis menunjukkan SPL tertinggi terjadi pada bulan Desember dan terendah terjadi di bulan Agustus. Pada bulan April yang dikenal sebagai musim peralihan tidak menunjukkan pola SPL yang jelas. Kondisi tersebut sangat dipengaruhi oleh sistem monsoon, yang mengakibatkan kondisi perairan mengalami perubahan. Kondisi tersebut diperkuat oleh [6], bahwa Laut Banda merupakan laut yang dipengaruhi oleh system monsoon (Gambar 2). Pola SPL dengan suhu minimum terjadi pada bulan juni sampai dengan agustus dan mencapai maksimum Desember sampai Februari kondisi tersebut disebabkan pengaruh ekman transport dan Ekman pumping [2], [7], [6]. Ekman pumping di Laut Banda memberikan kontribusi yang besar dalam proses upwelling pada periode monsun timur (JJA) dan selama monsun barat (DJF). Pengangkatan massa air (upwelling) maksimum terjadi pada periode JJA saat monsun timur ditunjukkan kondisi perairan SPL relatif rendah dan konsentrasi klorofil a mencapai nilai maksimum [5], [7]. Pola upwelling juga dapat dilihat dari distribusi vertical suhu dari permukaan sampai kedalaman lebih dari $200 \mathrm{~m}$ yang menunjukkan adanya stratifikasi. Stratifikasi SPL menunjukkan pada saat monsun timur kolom air di dominasi suhu dingin $<24^{\circ} \mathrm{C}$ dan pada saat monsun barat kolom air di dominasi suhu hangat $>29^{\circ} \mathrm{C}($ Gambar 3$)$.

\section{Distribusi Salinitas}

Sebagaimana halnya dengan distribusi SPL, pola distribusi salinitas yang ada di Laut Banda sangat dipengaruhi oleh system 


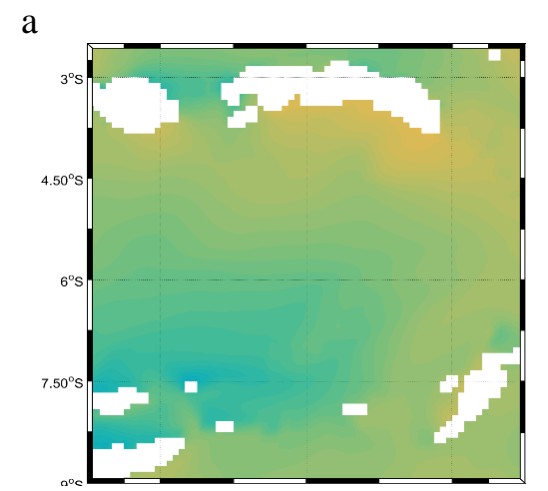

$\mathrm{d}$
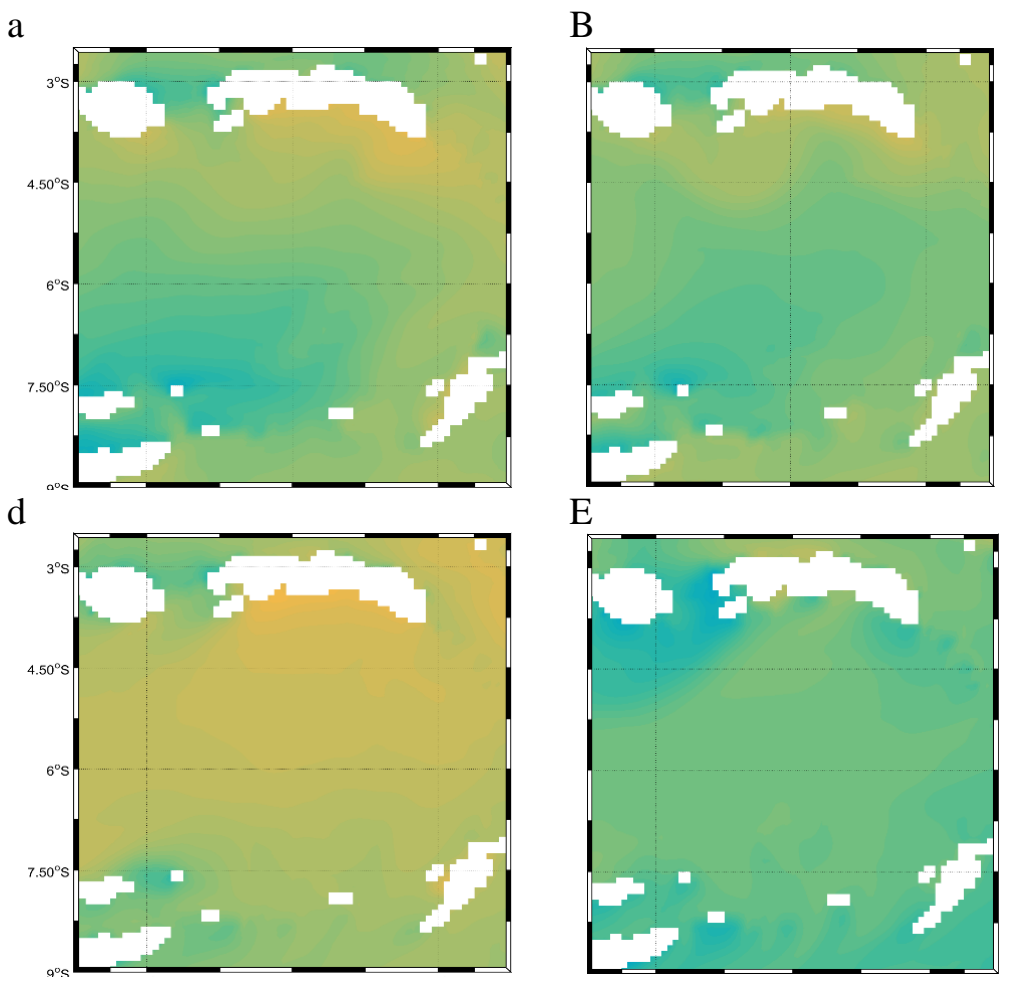

$\mathrm{E}$

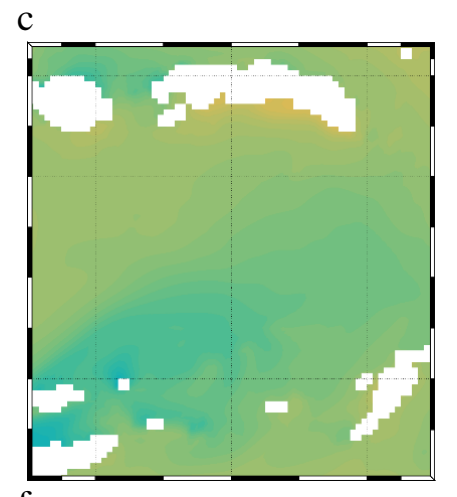

g
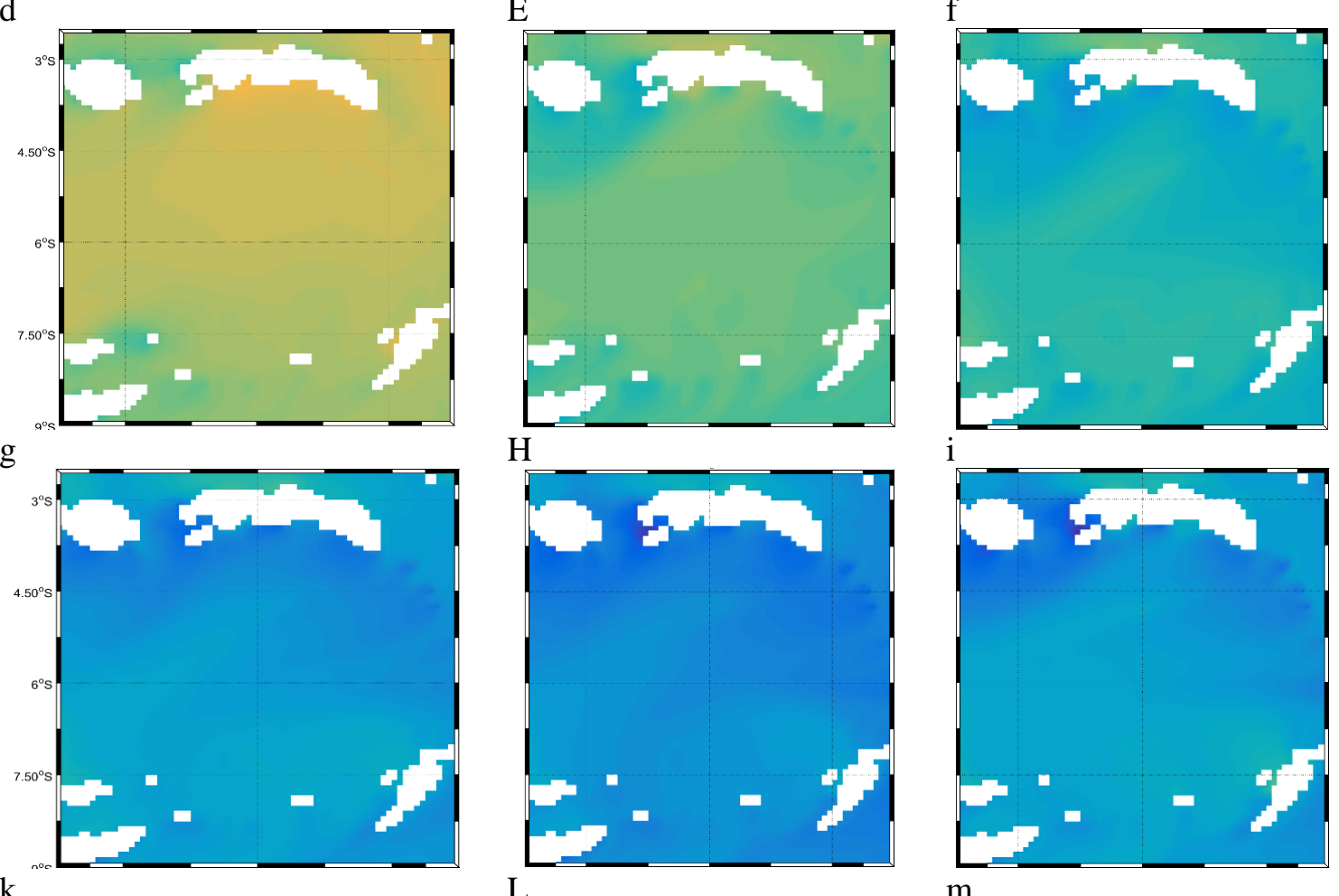

$\mathrm{k}$

$\mathrm{L}$

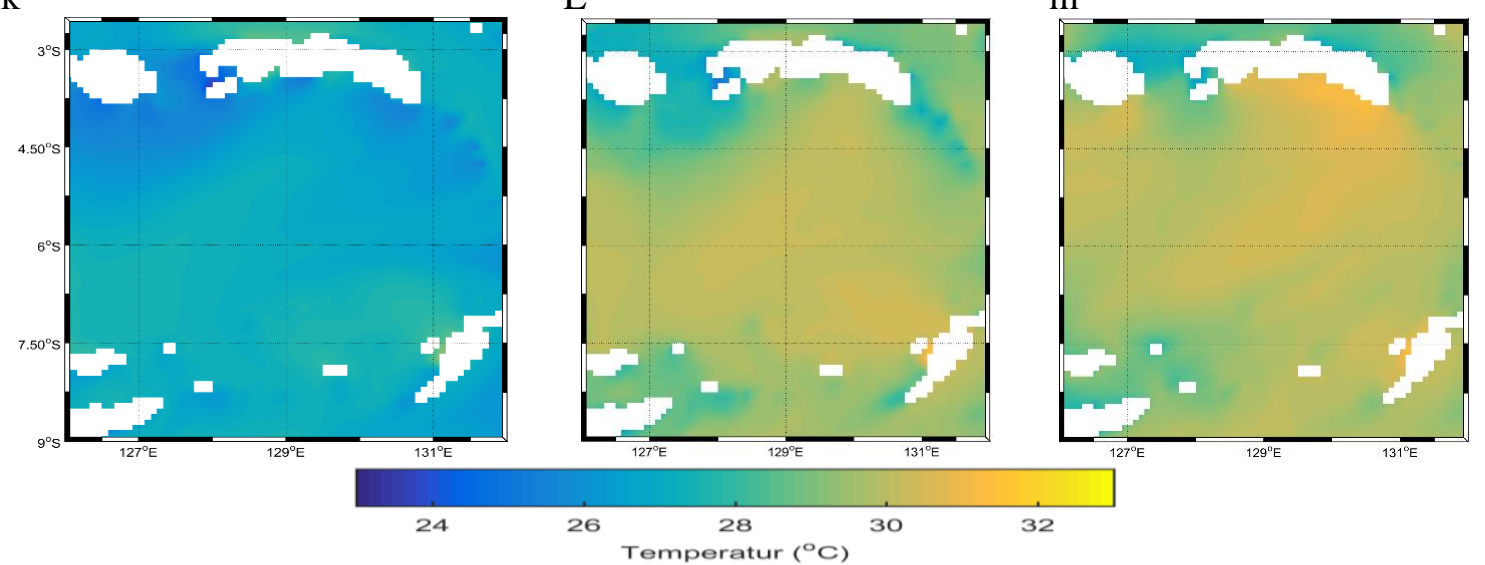

Gambar. 1. Pola SPL rerata bulanan di Laut Banda (a) Januari; (b) Februari; (c) Maret; (d) April; (e) Mei; (f) Juni; (g) Juli; (h) Agustus; (i) September; (j) Oktober; (k) November; (l) Desember. 
a

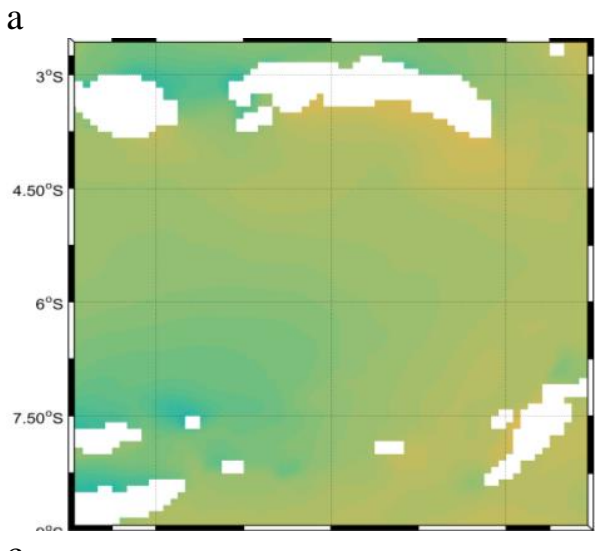

b

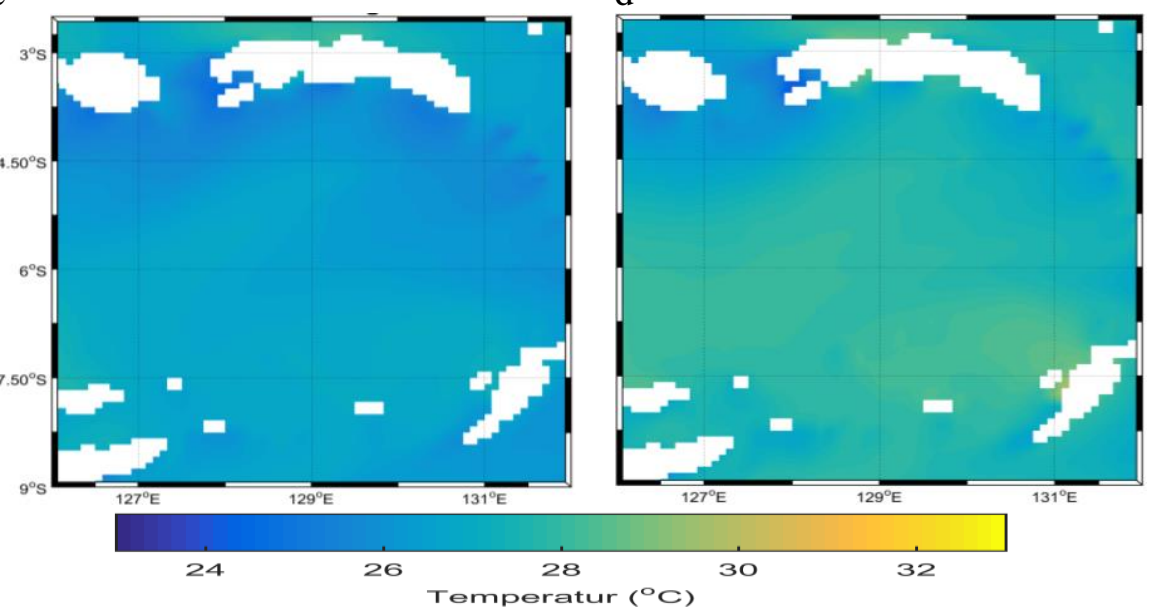

Gambar 2. Komposit SPL Musiman di Laut Banda (a) Desember-Januari-Februari (DJF); (b) Maret-April-Mei (MAM); (c) Juni-Juli-Agustus (JJA); (d) September-OktoberNovember (SON)

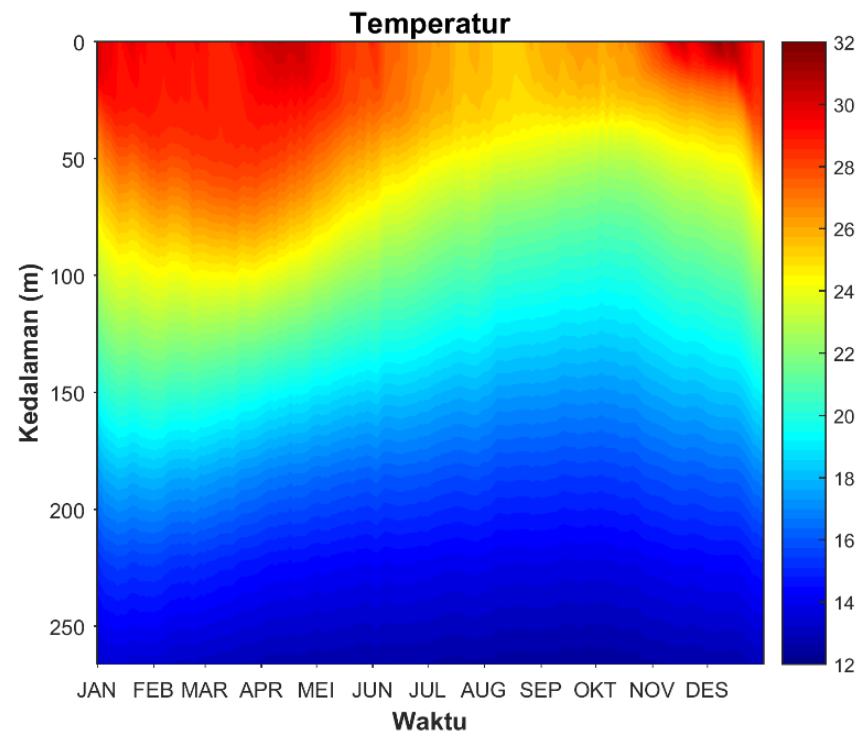

Gambar. 3. Distribusi vertikal suhu permukaan laut di Laut Banda 

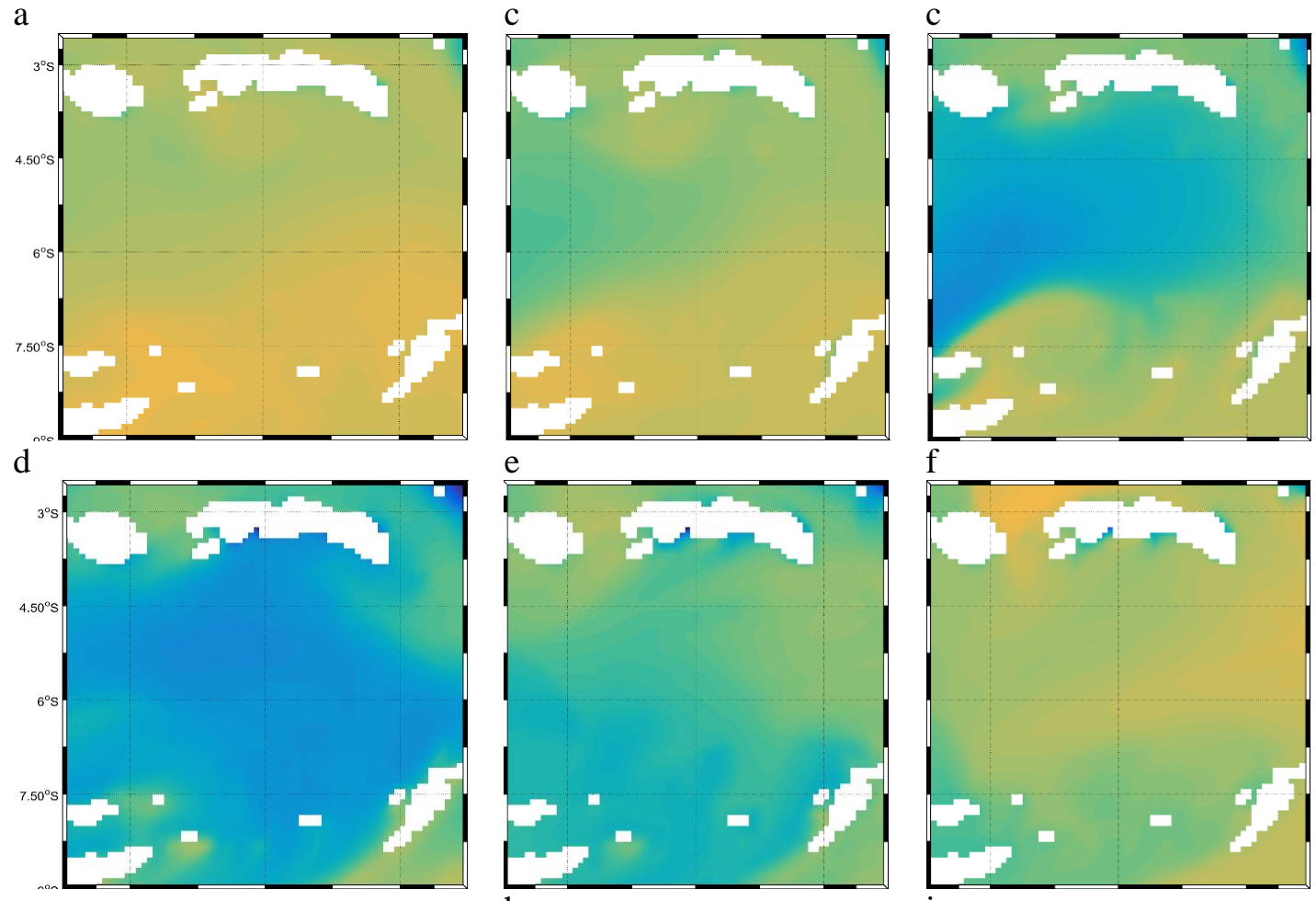

g
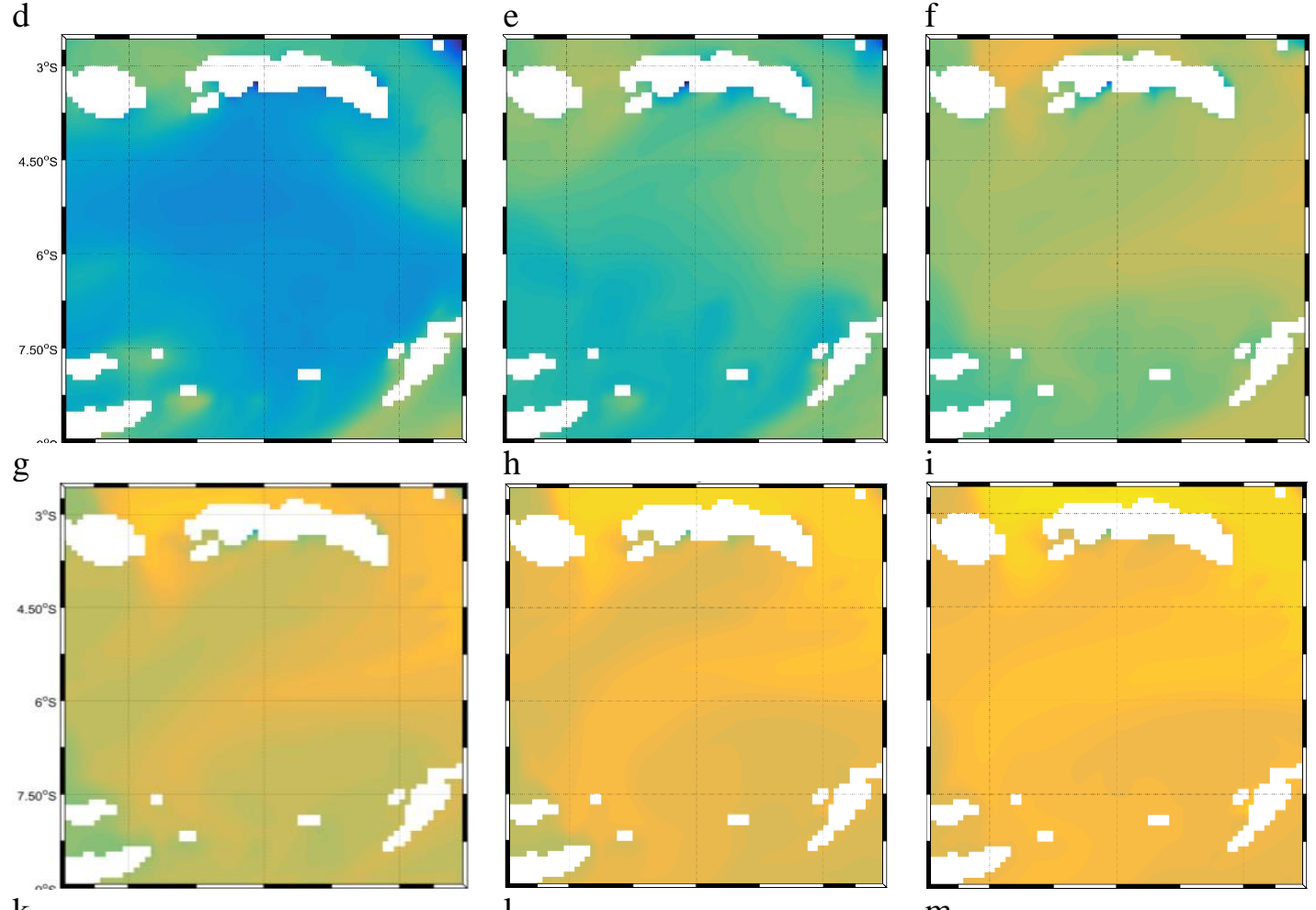

$\mathrm{k}$

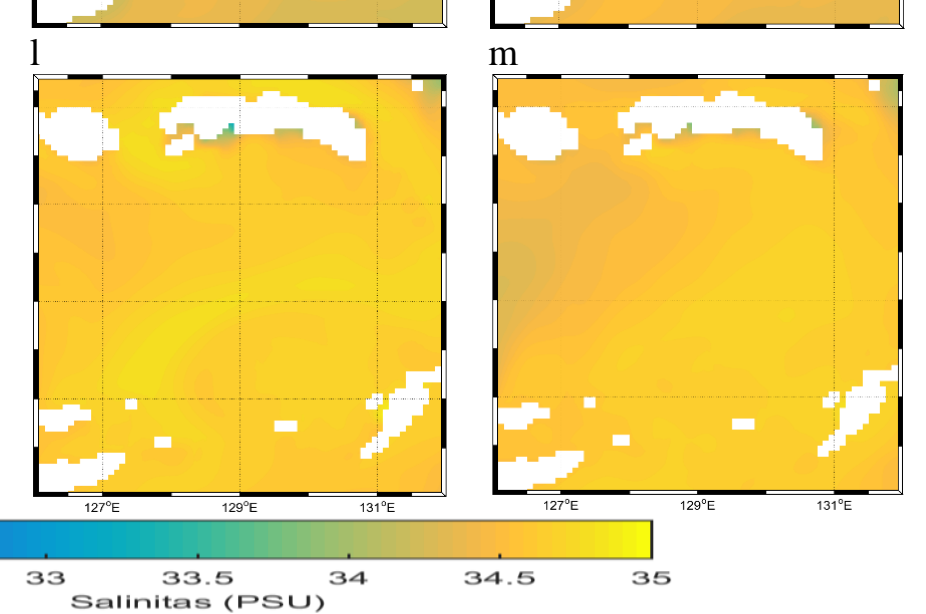

Gambar. 4. Pola Salinitas rerata bulanan di Laut Banda (a) Januari; (b) Februari; (c) Maret; (d) April; (e) Mei; (f) Juni; (g) Juli; (h) Agustus; (i) September; (j) Oktober; (k) November; (l) Desember 
monsun. Berdasarkan pada pola pergerakan arus yang dijelaskan oleh [1], banyak kemungkinan terjadinya proses percampuran dan pengaruh dari massa air dari wilayah lain terhadap karakteristik massa air Laut Banda. Pengamatan kondisi salinitas selama tahun 2015 berkisar antara 32 sampai dengan 35 PSU (Gambar 4). [1], mengklasifikasikan siklus di Laut Banda dalam 3 tipe. Pertama adalah perairan oseanik denga sanilitas lebih dari 34 PSU. Terjadinya intrusi massa air dengan salinitas tinggi ini sangat jelas terlihat pada waktu angin muson tenggara berhembus (Gambar 5). Massa air ke dua adalah yang bersalinitas 32 sampai dengan 34 PSU. Massa air tersebut berasal dari Samudera Hindia, percampuran sangat jelas pada waktu angina muson barat. Massa air ke tiga adalah massa air denga salinitas kurang dari 32 PSU yang sangat jelas terlihat di pantai Pulau Ambon dan Gususan Pulau disekitarnya. Sesuai dengan penelitian sebelumnya bahwa kondisi salinitas di Laut Banda mengikuti sistem monsun [8], dimana pada musim peralihan II (SON) merupakan nilai tertinggi berkisar antara 34,5-35 PSU, sedangkan terendah terjadi pada peralihan I (MAM) berkisar 3333,5 PSU. Distribusi vertical salinitas di Laut Banda pada periode monsun barat lebih tinggi di atas 34 PSU sampai pada kedalaman > 200 $\mathrm{m}$. sedangkan untuk periode monsun timur lebih rendah 33 PSU sampai kedalaman $<50$ $\mathrm{m}$, serta pada kedalaman > $100 \mathrm{~m}$ berkisar antara 34-34,5 PSU (Gambar 6).

\section{Distribusi Arus}

Parameter yang tidak kalah pentingnya adalah arus yang dibangkitkan oleh angin. Hasil perata-rataan arus total di Laut Banda selama tahun 2015 ditunjukkan pada (Gambar 7). Berdasarkan variasi temporal selama tahun 20 a

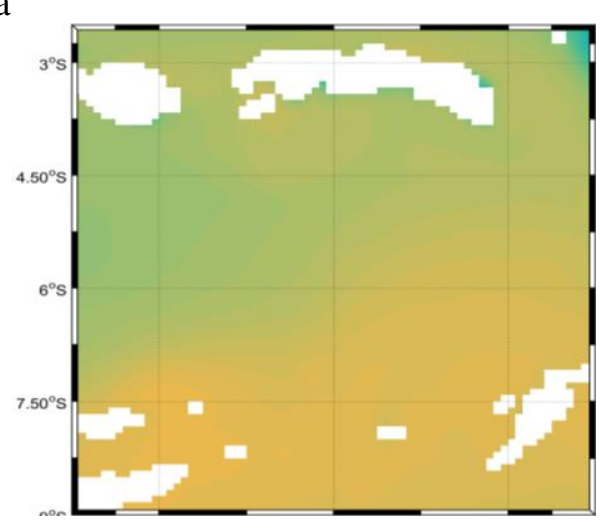

c

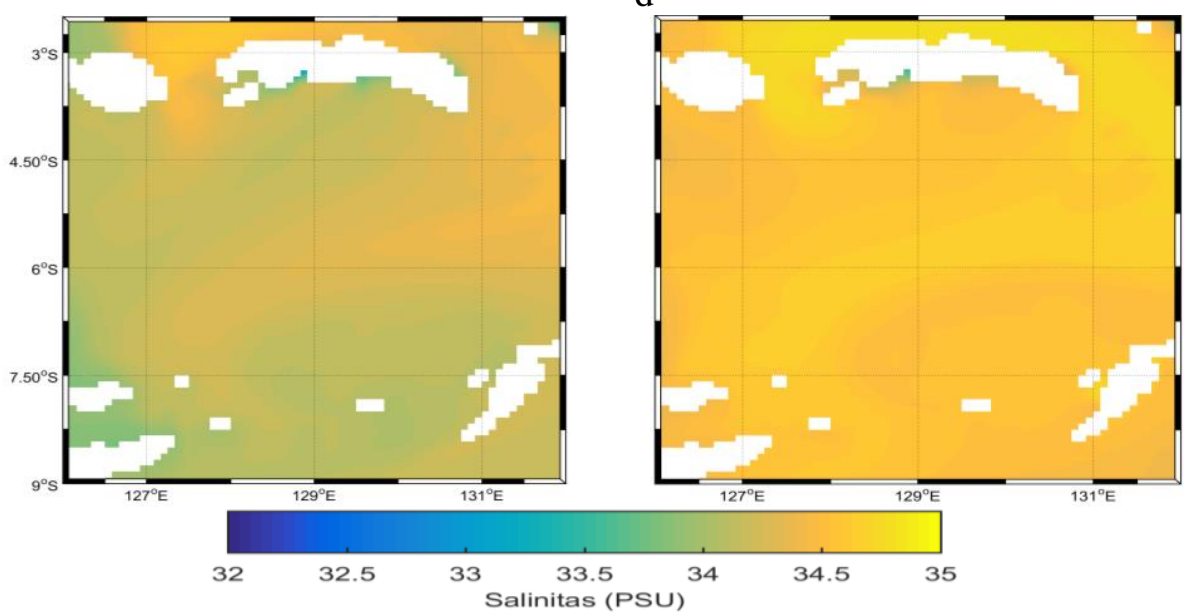

b

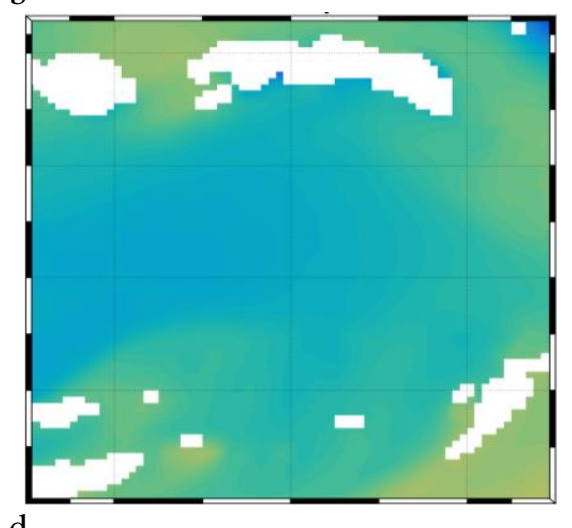

(a) Desember-Januari-Februari (DJF); (b)

Maret-April-Mei (MAM); (c) Juni-Juli-Agustus (JJA); (d) September-Oktober-November (SON) 
-15 ditunjukkan pada (Gambar 7). Berdasarkan variasi temporal selama pengamatan menurut [9], bahwa pada musim barat di lapisan permukaan mempunyai transport massa air sebesar $6.3 \mathrm{~Sv}\left(1 \mathrm{~Sv}=10^{6}\right.$ $\mathrm{m}^{3} / \mathrm{s}$ ) yang berarah ke timur, sedangkan antara 300 sampai 10000 dbar mempunyai transport massa sebesar 3.5 Sv ke arah barat. Pada periode JJA bertepatan dengan monsun timur Ekman pumping mencapai maksimum pada bulan Juli (Gambar 7 dan 8). Pola distribusi vertical memperkuat pengaruh monsun pada pergerakan arus total mencapai maksimum pada bulan juli dan minimum terjadi pada bulan desember. (Gambar 9).

\section{Variasi Paramter Oseanografi dan Potensi Produksi Perikanan}

Distibusi suhu, salinitas dan arus selama tahun 2015 menunjukkan perbedaan yang nyata antara periode monsun. Kondisi ini berpengaruh terhadap distribusi sumberdaya perikanan di Laut Banda Sebagaimana telah dikemukakan oleh beberapa peneliti sebelumnya bahwa rerata produtivitas primer kecenderungan meningkat pada bulan juli dan mencapai maksimum pada bulan Agustus. Pada bulan September dan oktober cenderung menurun dan stabil ketika bulan November dan Mei [5]. Berdasarkan hasil tangkapan total yang didaratkan di PPN Ambon pada tahun 2015 menunjukkan fluktuasi untuk komoditas ikan tuna, tongkol dan cakalang. Produksi tertinggi terjadi pada bulan Desember, Januari dan Pebruari sedangkan terendah terjadi pada bulan Juni, Juli dan Agustus (Gambar 10). Fluktuasi hasil tagkapan tersebut sangat dipengaruhi oleh pola monsun yang terjadi di Laut Banda sehingga mempengaruhi kondisi oseanogafi fisiknya. Sebagai parameter kunci dalam menetukan pola keberadaan sumberdaya perikanan ditunjukkan pada Tabel 1.

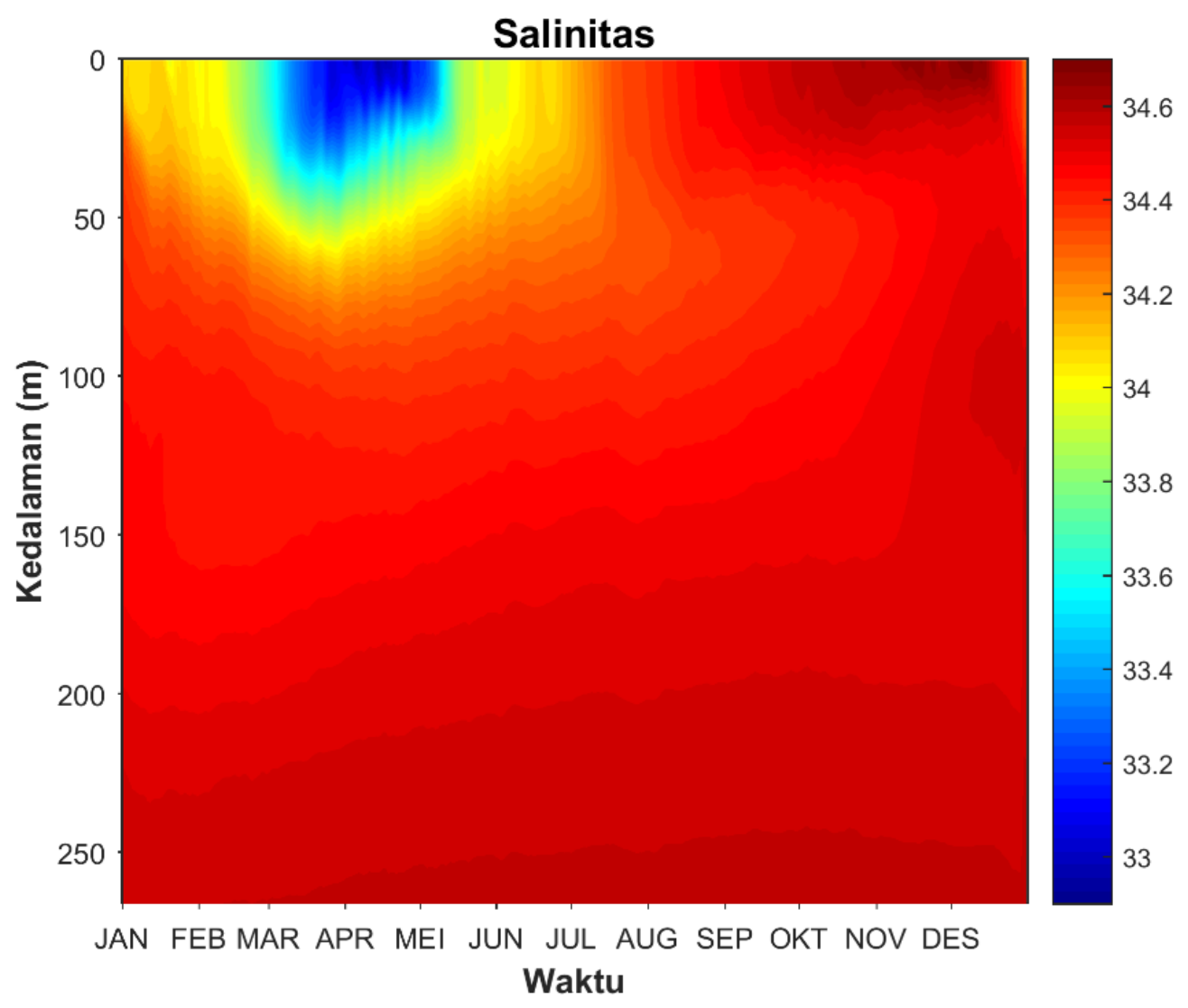

Gambar. 6. Distribusi vertikal Salinitas permukaan laut di Laut Banda 

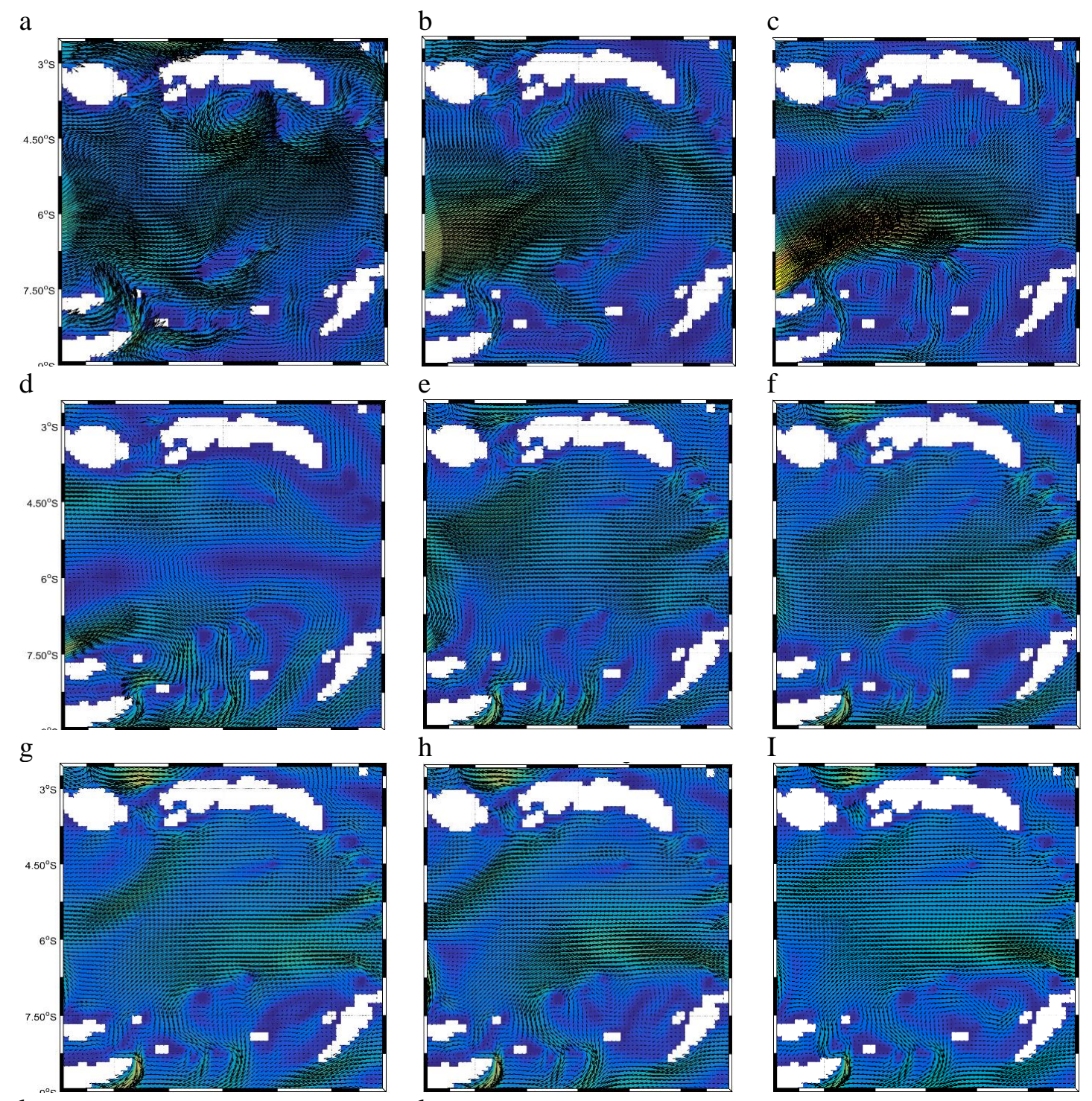

$\mathrm{k}$
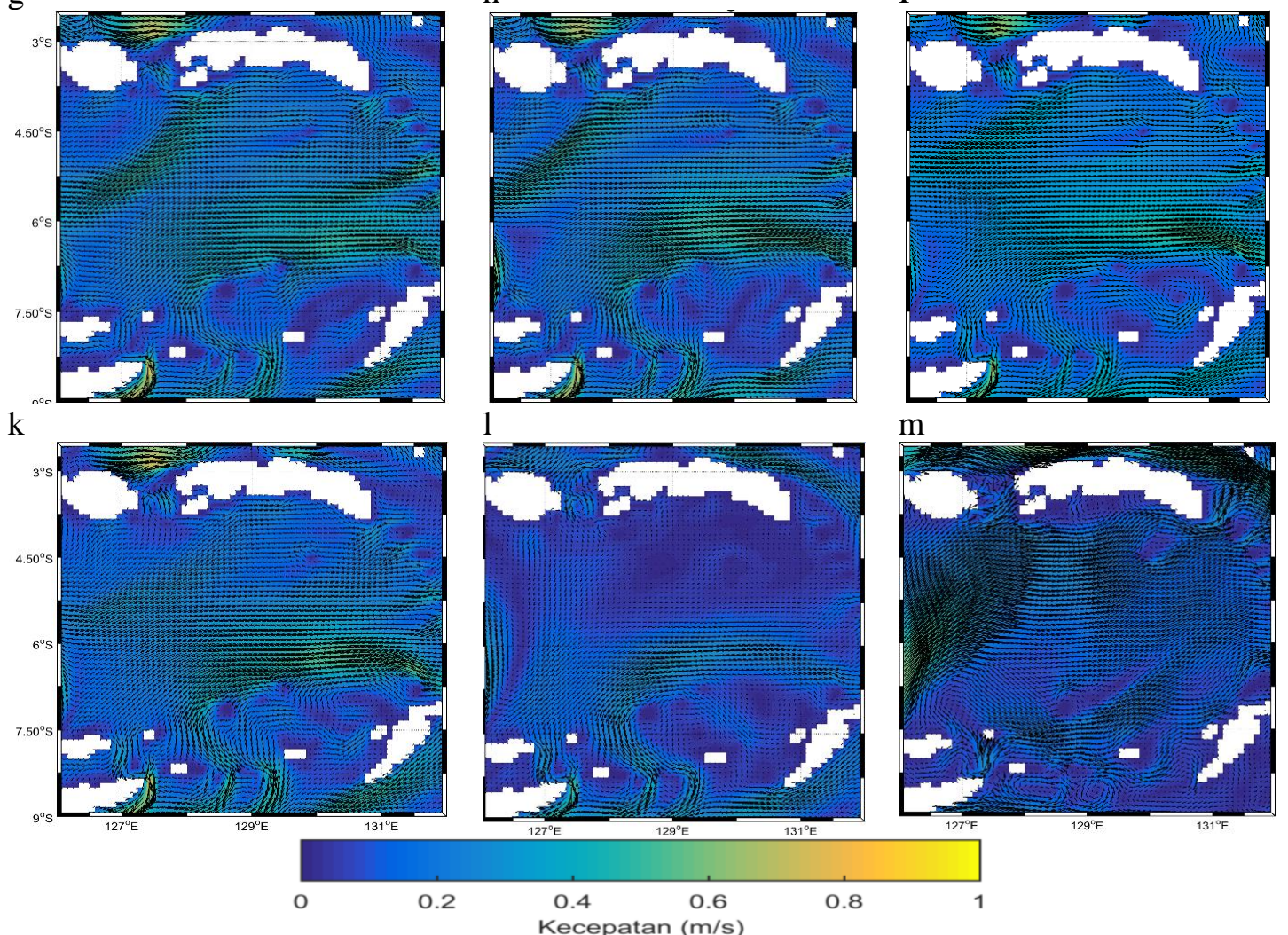

Gambar. 7. Pola Arus rerata bulanan di Laut Banda (a) Januari; (b) Februari; (c) Maret; (d) April; (e) Mei; (f) Juni; (g) Juli; (h) Agustus; (i) September; (j) Oktober; (k) November; (l) Desember. 


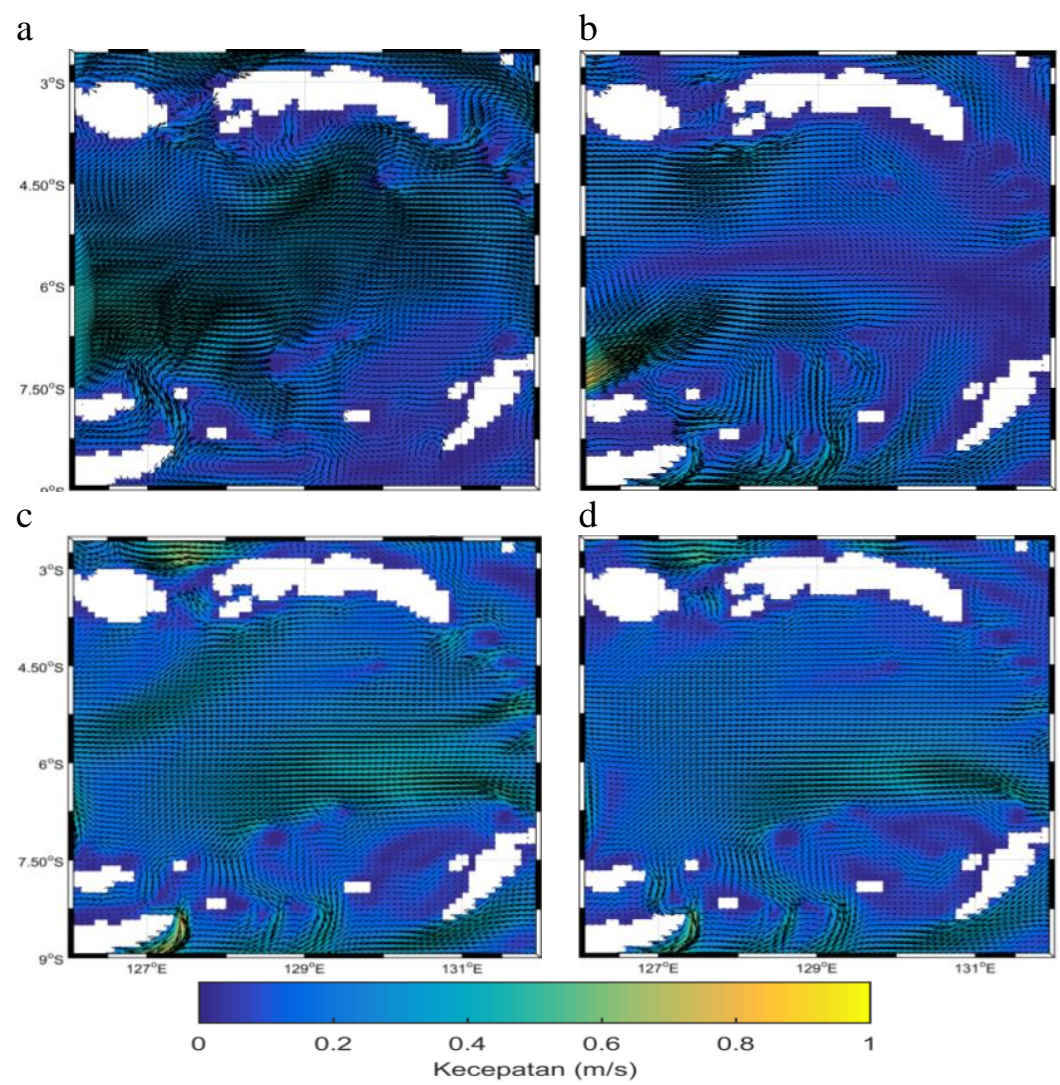

Gambar 8. Komposit Arus Musiman di Laut Banda (a) Desember-Januari-Februari (DJF); (b) Maret-April-Mei (MAM); (c) Juni-Juli-Agustus (JJA); (d) September-OktoberNovember (SON)

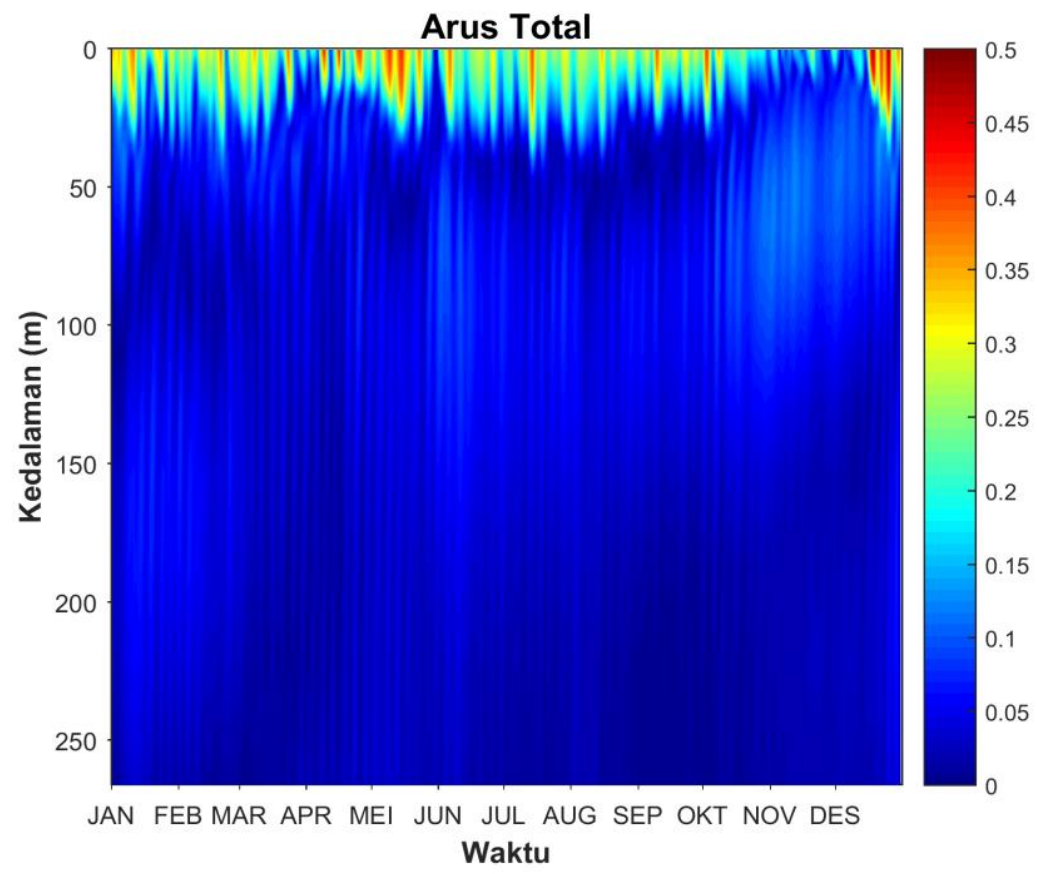

Gambar. 9. Distribusi vertikal arus permukaan laut di Laut Banda 


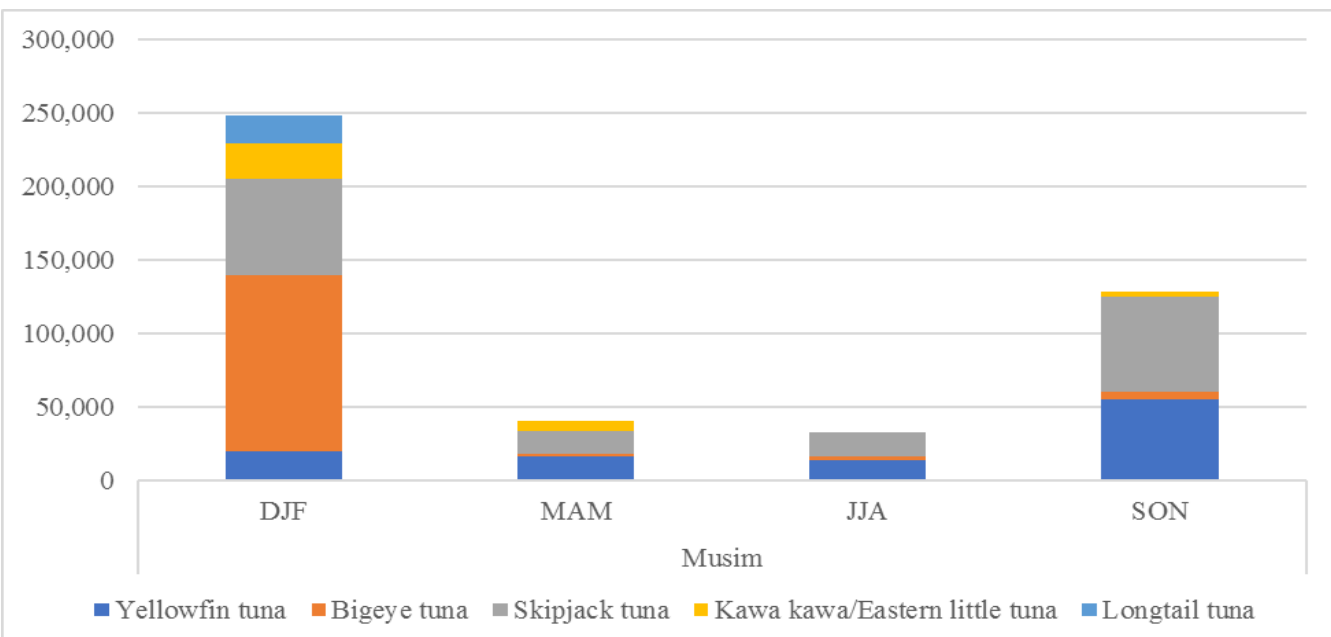

Gambar. 10. Fluktuasi musiman sumberdaya perikanan di Laut Banda

Tabel. 1. Parameter Oseanografi dan Jenis Ikan yang tertangkap

\begin{tabular}{|c|c|c|c|c|c|c|c|}
\hline \multirow{2}{*}{ No } & \multirow{2}{*}{ Jenis ikan } & \multirow{2}{*}{ Species } & \multicolumn{4}{|c|}{ Parameter Fisik } & \multirow{2}{*}{ Keterangan } \\
\hline & & & Suhu & Salinitas & Arus & Kedalaman & \\
\hline 1 & Madidihang & Yellowfin tuna & $22-28$ & $\begin{array}{c}34,4- \\
35,0\end{array}$ & $\begin{array}{c}0,10- \\
0,05\end{array}$ & $>200$ & \\
\hline 2 & $\begin{array}{l}\text { Tuna mata } \\
\text { besar }\end{array}$ & Bigeye tuna & $10-15$ & $\begin{array}{c}34,1- \\
35,0\end{array}$ & $\begin{array}{c}0,10- \\
0,05\end{array}$ & $>200$ & $\begin{array}{l}\text { Gaol, J.L., et al., } \\
2015 \text { [10] }\end{array}$ \\
\hline 3 & Cakalang & Skipjack tuna & $29-31,5$ & $\begin{array}{c}31,0- \\
33,0\end{array}$ & $\begin{array}{c}0,15- \\
0,30\end{array}$ & $<100$ & $\begin{array}{l}\text { Zainuddin, M., } \\
\text { et al., } 2017 \text { [11] }\end{array}$ \\
\hline 4 & $\begin{array}{l}\text { Tongkol } \\
\text { komo }\end{array}$ & $\begin{array}{l}\text { Kawa } \\
\text { kawa/Eastern little } \\
\text { tuna }\end{array}$ & $20-22$ & $\begin{array}{c}32,2- \\
34,4\end{array}$ & $\begin{array}{c}0,15- \\
0,30\end{array}$ & $<100$ & $\begin{array}{ll}\text { Girsang, } & \text { H.S., } \\
2008[12] & \end{array}$ \\
\hline 5 & $\begin{array}{l}\text { Tongkol } \\
\text { abu-abu }\end{array}$ & Longtail tuna & $20-22$ & $\begin{array}{c}32,2- \\
34,4\end{array}$ & $\begin{array}{c}0,15- \\
0,30\end{array}$ & $<100$ & $\begin{array}{l}\text { Girsang, H.S., } \\
2008 \text { [12] }\end{array}$ \\
\hline
\end{tabular}

\section{KESIMPULAN}

Karakteristik oseanografi fisik seperti suhu, salinitas, dan arus menunjukkan hubungan dengan peningkatan hasil tangkapan ikan. Berdasarkan data ikan tuna tertangkap pada kisaran suhu $16-18^{\circ} \mathrm{C}$, salinitas 34-34,5 PSU, arus 0,1-0,05 m/s pada kedalaman $>200 \mathrm{~m}$; ikan tongkol tertangkap pada kisaran suhu $26-28^{\circ} \mathrm{C}$, salinitas $34-34,5$ PSU, arus 0,1-0,05 m/s pada kedalaman $<100$ $\mathrm{m}$; dan ikan cakalang tertangkap pada kisaran suhu $29-31^{\circ} \mathrm{C}$, salinitas $31-33 \mathrm{PSU}$, arus $0,15-$ $0,30 \mathrm{~m} / \mathrm{s}$ pada kedalaman $<100 \mathrm{~m}$.

Kondisi oseanografi fisik Laut Banda pada kedalaman $<100$ dan $>200 \mathrm{~m}$, selama tahun 2015 menunjukkan pola peningkatan hasil tangkapan pada setiap musim. Peningkatan tertinggi pada musim peralihan II (September - November) dan barat (Desember
- Februari) sedangkan pada musim peralihan I (Maret - Mei) dan timur (Juni - Agustus) mengalami penurunan.

\section{UCAPAN TERIMAKASIH}

Ucapan terimakasih disampaikan kepada semua pihak yang membantu terlaksananya penelitian ini. Penelitian ini merupakan bagian dari penelitian "Operasional Oseanografi untuk Prediksi Dinamika Laut" yang di biaya pada DIPA BPOL 2016 dan INDESO Program serta PPN Ambon.

\section{REFERENCES}

[1] Wyrtki, K. 1961. Physical Oceanography of the South-East Asian Waters, Naga Report 2: 1-195. 
[2] Ratnawati, I. R., Hidayat, R., Bey, A., June, T., 2016. Upwelling di Laut Banda dan Pesisir Selatan Jawa serta Hubungannya dengan ENSO dan IOD. http://dx.doi.org/10.20884/1.oa.2016.12 .3 .134 .

[3] Waileruny, Welem., 2014. Pemanfaatan Berkelanjutan Sumberdaya Perikanan Cakalang (Katsuwonus pelamis) di Laut Banda dan Sekitarnya Provinsi Maluku. Disertasi Sekolah Pascasarjana Institut Pertanian Bogor. Bogor Gaol, J.L., dan Sadhotomo, B., 2007. Karakteristik dan Variabilitas Parameter-Parameter Oseanografi Laut Jawa Hubungannya dengan Distribusi Hasil Tangkapan Ikan. http://DOI:10.15578/jppi.13.3.2007.201 $-201$

[4] Iskandar, Iskhaq., 2010. Seasonal and interannual pattern of sea surface temperature in Banda Sea as revealed by self-organizing map. Continental Shelf Research 30 (2010); pp. 11361148, doi:10.1016/j/csr.2010.03.003

[5] Sukresno, B dan Suniada, K.I., (2010). Observasi Pengaruh ENSO Terhadap Produktivitas Primer dan Potensi Perikanan dengan Menggunakan Data Satelit di Laut Banda. Globe Valume 10 No. 2 Desember 2008: 97-107.

[6] Gordon, A.L., and Sudanto, R.D., 2001. Banda Sea Surface layer divergence. https://doi.org/10.1007/s10236-0018172-6

[7] Hendiarti, N., Suwarso, E., Aldian, E., Amri, K., Andiastuti, R., Sachoemar, S., Wahyono, I., 2005. Seasonal Variation of Pelagic Fish Catch Around
Java. Journal Oceanography. Vol 18. Oceanography Society-Rockville.

[8] Setiadi, A., 2004. Efek Upwelling Terhadap Kelimpahan dan Distribusi Fitoplankton di Perairan Banda dan Sekitarnya. Makara, Sains, Vol. 8 No.2, Agustus 2004: pp 43-41.

[9] Gordon, A., Ffield, A., Illahude, A.G., 1994. Thermocline of the Flores and Banda Sea. J. Geophys. Res Vol:99 No:C9, hal 18.235-18.242.

[10] Gaol, J.L., Nurjaya, I. W., Amri, K., 2015. Dampak Perubahan Iklim Terhadap Kondisi Oseanografi dan Laju Tangkap Tuna Mata Besar (Thunnus obesus) di Samudera Hindia Bagian Timur. Simposium Nasional Pengelolaan Perikanan Tuna Berkelanjutan. Bali. VI 96-104.

[11] Zainuddin M, Farhum A, Safruddin S, Selamat MB, Sudirman S, Nurdin N, et al. (2017) Detection of pelagic habitat hotspots for skipjack tuna in the Gulf of Bone-Flores Sea, southwestern Coral Triangle tuna, Indonesia. PLoS ONE 12(10): e0185601. https://doi.org/10.1371/journal.pone.01 85601

[12] Girsang, H. S., 2008. Studi Penentuan Daerah Penangkapan Ikan Tongkol melalui pemetaan penyebaran klorofil-a dan hasil tangkap di Palabuhanratu, Jawa Barat. Skripsi. Departemen Pemanfaatan Sumberdaya Perikanan Fakultas Perikanan dan Ilmu Kelautan Institut Pertanian Bogor. Bogor. 